\title{
Smallholder Farmers' Perception of Climate Change and Variability Impact and Their Adaptation Strategies in the Upper and Lower Niger River Basin Development Authority Areas, Nigeria
}

\section{Babatolu $\mathrm{JS}^{1^{*}}$ and Akinnubi $\mathbf{R T}^{2}$}

${ }^{1}$ Department of Geography, Adeyemi Federal University of Education, Ondo, Nigeria

${ }^{2}$ Department of Physics, Adeyemi Federal University of Education, Ondo, Nigeria

\begin{abstract}
The work attempted to analyze vulnerabilities and adaptation responses of smallholder farmers in the Upper and Lower Niger River Basin Development Authority areas (U \& LNRBDA). Qualitative data was used in this study. The qualitative data was collected using questionnaire method. One thousand and two hundred questionnaires (1200) were administered out of which one thousand and one hundred and twenty-four (1124) were returned for analysis. The research findings revealed that there is high level of climate change awareness in the study area. A significant number of the smallholder farmers attested to the fact that they were aware of the changing climate-increasing temperatures, unpredictable, erratic, heavy and increasing rainfall, late onset and early retreat of rains. This is validated by the various empirical studies in the region. Smallholder farmers in the study areas really possess knowledge of the impacts of climate change and variability which helped them to cope with climate change and variability. They were able to identify their areas of vulnerability and appropriate adaptation options in their own capacity. It is recommended that the government needs to build on their capacity, knowledge and practices to enhance resilience of the smallholder farmers and for sustainability of adaptation strategies to climate change and variability.
\end{abstract}

Keywords: Climate Change; Variability; Impact; Adaptation; Smallholder farmers; Upper and Lower Niger River Basin Development Authority Areas (U \& LNRBDA)

\section{Introduction}

Nigeria is already experiencing a range of climate changes including more frequent heavy rainfall events, erratic rainfall, and unpredictable onset/retreat of rain and increasing air temperature. The impacts from these changes are already threatening ecosystems, food production, livelihoods and infrastructure. These changes are not uniform in the country as some areas are severely impacted and hence more vulnerable to climate change than others. The impacts of climate change are expected to be more pronounced in the developing countries particularly in Sub-Saharan Africa because their livelihood is dependent on nature which is highly sensitive to climate change [1]. Unfortunately, agriculture which is highly vulnerable to climate is an important sector in the economy of most developing countries particularly Nigeria. Smallholder farmers constitute the single most important occupational group in Nigerian and contribute significantly to the national economy. According to Falaki agriculture employs over 70 percent of the population, contributes about 41 percent of gross domestic product (GDP) [2], accounts for 5 percent of total export and provides 88 percent of non-oil earnings in Nigeria. The economies of most of the developing countries are dependent on agriculture which employs about 60 percent of the labour force and accounts for 30 per cent GDP in Sub-Saharan Africa [3]. Climate change expressed in high temperature, frequent floods, unpredictable onset and retreat of rains and droughts posed constraints on agriculture in Nigeria. The effects have direct impact on smallholder farmers in the study areas. Their vulnerability is inextricably linked with severe poverty high levels of illiteracy, weak institutions and infrastructure, low technology, poor governance and reliance on nature for their livelihood. The smallholder farmers who are the major producer of food crops are increasingly finding it difficult to cope with hazards of climate change and variability [4].

Adaptation is fastly becoming one of the policy options to reduce the negative consequences of climate change and variability in developing countries that unfortunately contribute little to the change. The losses from climate change may slow down the rate of development in the country. Nigeria has lived with climate change and variability over some decades without given it much attention but now they have already had obvious impacts on economies, biodiversity, people and health. The highly variable rainfall (intensity, distribution, and amount), increasing temperature, frequent floods and droughts as are currently being experienced in Nigeria could lead to greater uncertainty and increase risks for farmers and even potentially erode the value of traditional agricultural knowledge such as when to plant a particular crop. Adaptation is the only option left for survival in the face of these changes in climate and this should be before the farming conditions deteriorate further.

Climate change adaptation may be regarded as response to climate change impacts. Climate changes adaptation according to IPCC is the adjustment in ecological and socio-economic systems to the actual or anticipated climate change in order to reduce the negative and enhance the positive impacts of climate change [1]. Adaptation is simply changes the society needs to make to ameliorate climate change impact. Low level smallholder farmers awareness may adversely affect their resiliency to climate change impacts as awareness is crucial in coping with or preparing for climate change and variability. The level of smallholder farmer's knowledge of their environment could be a guide to respond effectively to the challenges of climate change and improve

"Corresponding author: Babatolu JS, Department of Geography, Adeyem Federal University of Education, Ondo, Nigeria, E-mail: rufus782000@yahoo.com

Receive May 07, 2016; Accepted June 07, 2016; Published June 15, 2016

Citation: Babatolu JS, Akinnubi RT (2016) Smallholder Farmers' Perception of Climate Change and Variability Impact and Their Adaptation Strategies in the Upper and Lower Niger River Basin Development Authority Areas, Nigeria. J Pet Environ Biotechnol 7: 279. doi:10.4172/2157-7463.1000279

Copyright: (c) 2016 Babatolu JS, et al. This is an open-access article distributed under the terms of the Creative Commons Attribution License, which permits unrestricted use, distribution, and reproduction in any medium, provided the original author and source are credited. 
Citation: Babatolu JS, Akinnubi RT (2016) Smallholder Farmers' Perception of Climate Change and Variability Impact and Their Adaptation Strategies in the Upper and Lower Niger River Basin Development Authority Areas, Nigeria. J Pet Environ Biotechnol 7: 279. doi:10.4172/21577463.1000279

Page 2 of 7

productivity. Unfortunately not much is known about the smallholder farmers' awareness and knowledge of climate change in Nigeria and particularly in the Upper and Lower Niger River Basin Development Authority areas (U \& LNRBDA).

Although some efforts have been made to investigate smallholder farmers' perception of climate change and variability and their adaptive strategies [2,5-9], there is still limited literature regarding understanding how farmers perceive and manage climate change. Moreover none of the works focused on U \& LNRBDA, an area where rainfall is highly variable and barely adequate to support rainfed farming. This study attempts to fill these gaps by investigating the smallholder farmers' perception of climate change, its impact on their agricultural practices and their coping strategies in the U\&LNRBDA. Specifically the study investigates:

a) Smallholder farmers' awareness of climate change

b) Smallholder farmers' perception of the impact of climate change and variability on agricultural practices.

c) Smallholder coping strategies with climate change and variability impacts.

\section{Materials and Methods}

\section{Area of the study}

The U \& LNRBDA areas lie mainly between latitude $7^{\circ} \mathrm{N}$ and $12^{\circ} \mathrm{N}$ and between longtitudes $3^{\circ} \mathrm{E}$ and $9^{\circ} \mathrm{E}$ in Nigeria (Figure 1). It is a transitional zone between the coastal and the Sahel. Precisely it lies within the Sudano-Sahelian belt. Its geographic extent includes the whole of Kwara, Kaduna and Niger States as well as Federal capital Territory and part of Kogi State (Figure 2). The livelihood systems of the inhabitants include arable farming, livestock herding, fishing and trading. Farming in this region is almost entirely reliant on five to six months of rainfall (April/May to September) except along the bank of the major rivers and other perennial water courses, where irrigation activities are undertaken. Yam, cassava, maize, guinea corn, millet and rice constitute most of the staple foods of the inhabitants.

The reasons for the vulnerability of the study area include the fact that U \& LNRBDA areas is located within Nigerian's middle belt where the annual rainfall is highly seasonal and erratic in distribution and water supplies are already stressed to a level barely adequate to satisfy the various demands. Marked variation in annual rainfall from year to year is one of the salient feature of the climate of this region. The survival of the inhabitants of this region is anchored on their indigenous knowledge of these characteristics. Nevertheless climate change and variability still remain one of the major threats to quality and quantity of food production in the study area.

In the period 1941-2010, the study areas experienced two drought episodes, 1941-1950 and the long period of sustained declining rainfall that spanned 1970-1993 and two wet periods of wet years 1951-1969 and 1994-2010. These expose the variability of the climate of the region.

Also soils in the study area are low in fertility, variable in water content and prone to erosion. It therefore requires good management to avert rapid depletion of fertility and sustain production for a reasonable time. In this region, maintaining soil fertility, whether through organic or in organic sources is one of the keys to sustainable agriculture. Whereas the soil is virtually all parts of the study area is inherently fragile and prone to degradation. The nature of the rainfall does not make the situation better. Rainfall in the area is becoming heavier, making water absorption by the soil difficult and hence leading to soil erosion. The situation is made worse by rapid increase in population and expansion of farms.

Again, the region is housing the most important hydroelectricity power stations of the country and water resources are also very sensitive to climate variability.

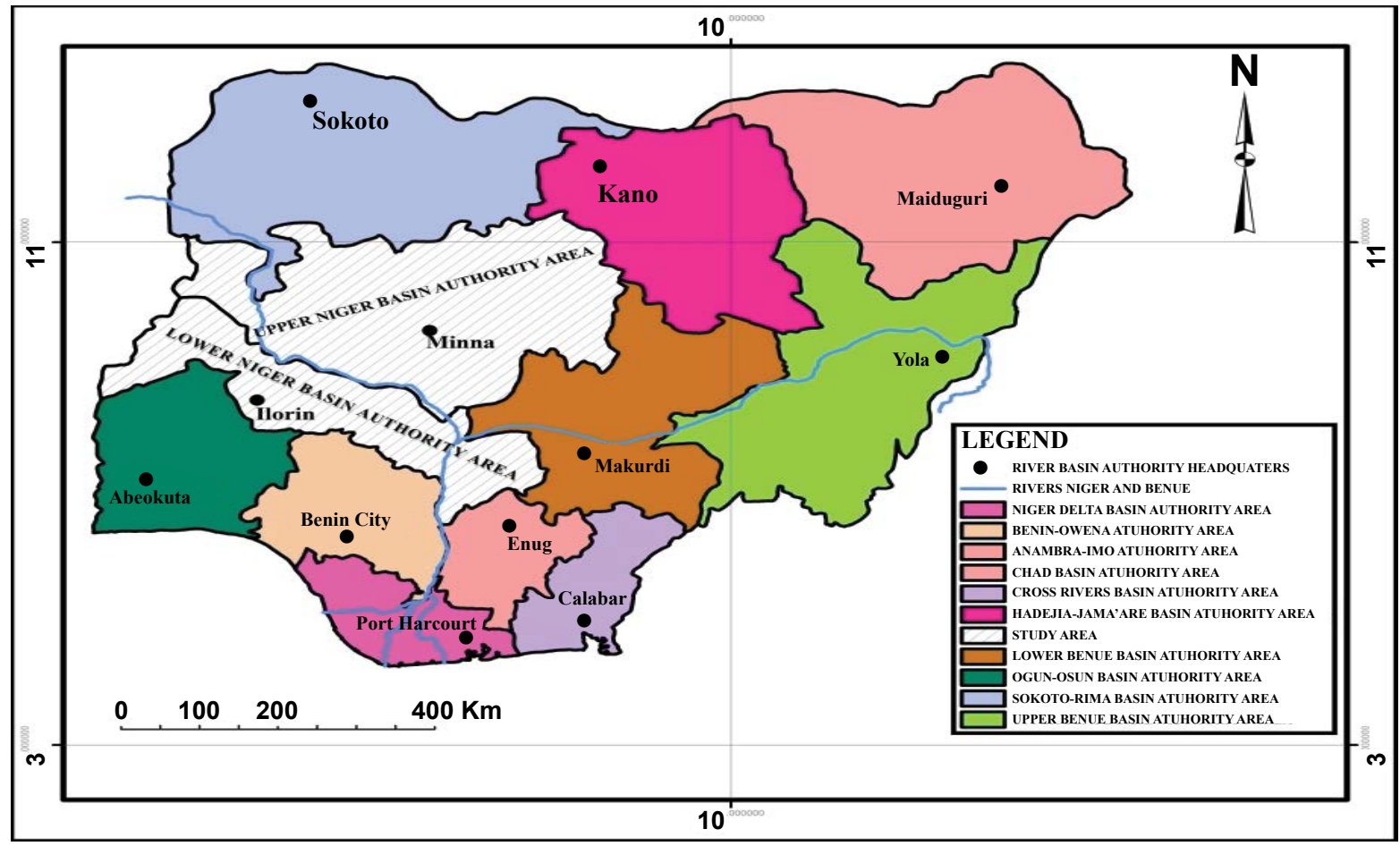

Figure 1: Map of Nigeria showing the upper and lower Niger River basin development authorities. 


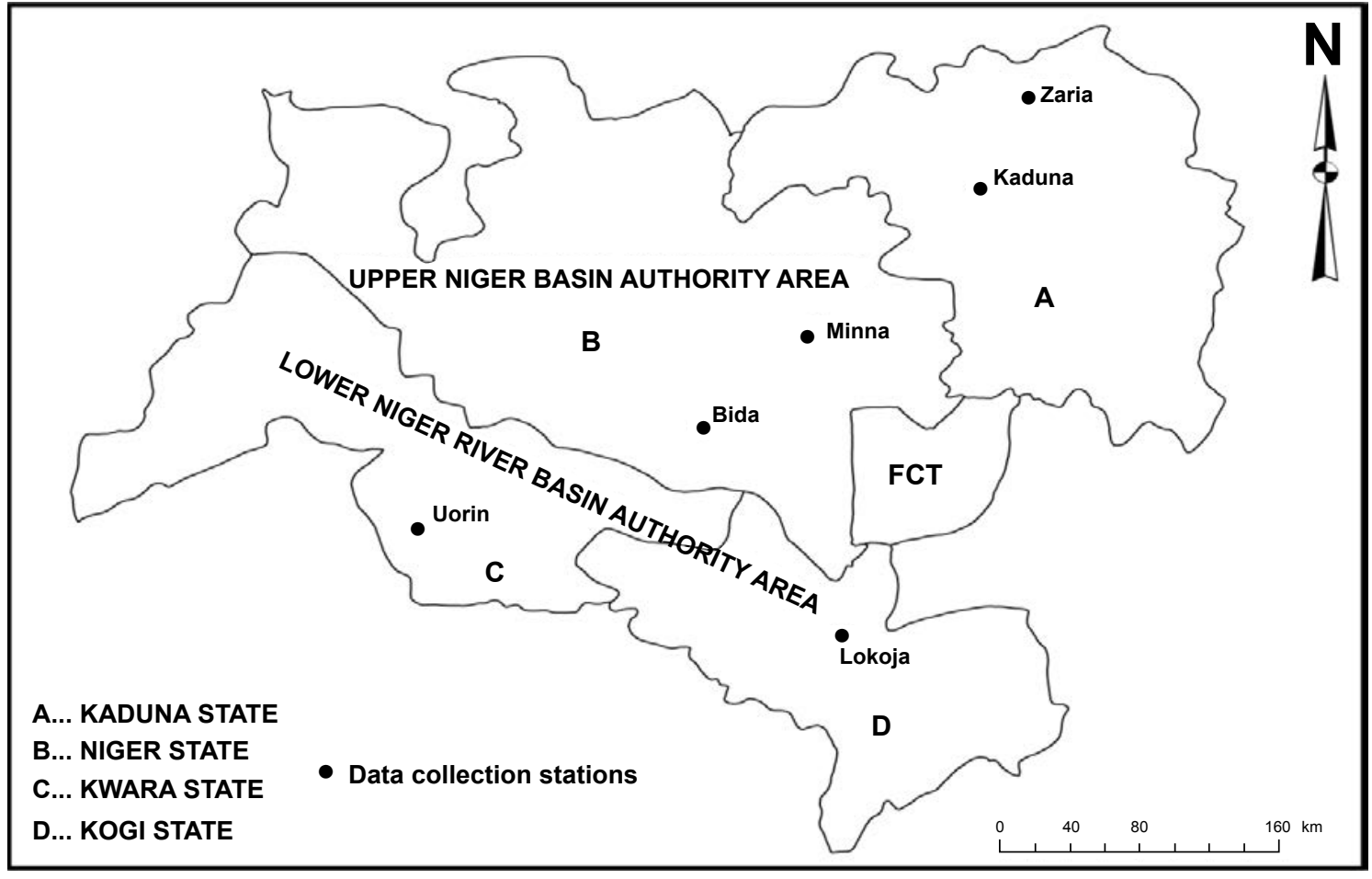

Figure 2: Map of the upper and lower Niger River basin development authorities showing climate data collection stations.

\section{Data collection and analysis}

A total of 1200 farmers were targeted for this study; using multistage random sampling technique. Two Local Government Areas (LGA) were randomly selected from each of the senatorial zones of each State. From each of the selected LGAS, five village communities were randomly selected. Purposive sampling was employed to select ten smallholder farmers with thirty years and above farming experience from each of the five village communities. Farmers with less than thirty years farming experience were not reckoned with for the study because they would not be able to give fair picture of the needed perception and good evidence of climate changes and variability.

Quantitative data was collected for this study. The instrument used for data collection was a structured questionnaire. The questionnaire collected information on smallholder farmers' perception on climate change and variability; response to the impact of climate change and variability and smallholder farmers' coping strategies. The questionnaire was translated into local languages by interviewers for the farmers that could neither read nor write. 1124 out of 1200 questionnaires administered were returned.

Descriptive statistics including frequency and percentage presented in tables were employed to analyze data from the questionnaires.

\section{Results and Discussion}

\section{Important food crops produced in the study area}

The smallholder farmers in the study area cultivate a diversity of crops and varieties in time and space with local technology. The climate of the study area permits the production of both root and grains crops. The cultivation of diverse crops reduces shocks of climate extremes and increase total harvest. The various food crops produced by the respondents are listed in Table 1.
Table 1 shows that yam is the most popular food crop in the study area which is closely followed by maize and cassava. Traditionally cassava was not popular until quite recently when the Federal Government encouraged the farmers to produce it for exports. It must however, be remarked that these results differ from one Local Government Areas to another and one state to another. According to the respondents, the crops are highly sensitive to climate change and variability except cassava and swampy rice. It was observed that smallholder farmers can cultivate about two to three crops on the same plot. For instance planting of yam, maize and cassava or guinea corn, yam and melon on the same plot is normal in the study area but at different time of the growing season. Other minor food crops include soyabean, cocoyam and sweet potato.

\section{Smallholder farmers' perceptions of long-term climate change and variability in the study area}

The study area experienced regular floods and drought that threaten the socioeconomic well-being of the inhabitants. According to the farmers the rains that used to come regularly during the planting season were becoming more erratic and whenever they came they were often in heavy bursts that caused floods and little infiltration.

Figure 3 shows that 70 percent of the respondents in the study area perceived that there was an increase in temperature over the last 30 years. According to some of the respondents, it had been noted that over the last 30 years hot condition prevailed in the study areas for most of the years both during the day and night. Figure 3 also shows that majority of the respondents (50.5\%) perceived increase in rainfall while 30 percent of the respondents perceived that there has been no change in annual rainfall but year to year variation. A significant number of respondents perceived that rain days with heavy rainfall were increasing. This must have been due to rampant flood events as some of them narrated their ordeal from incessant floods which 


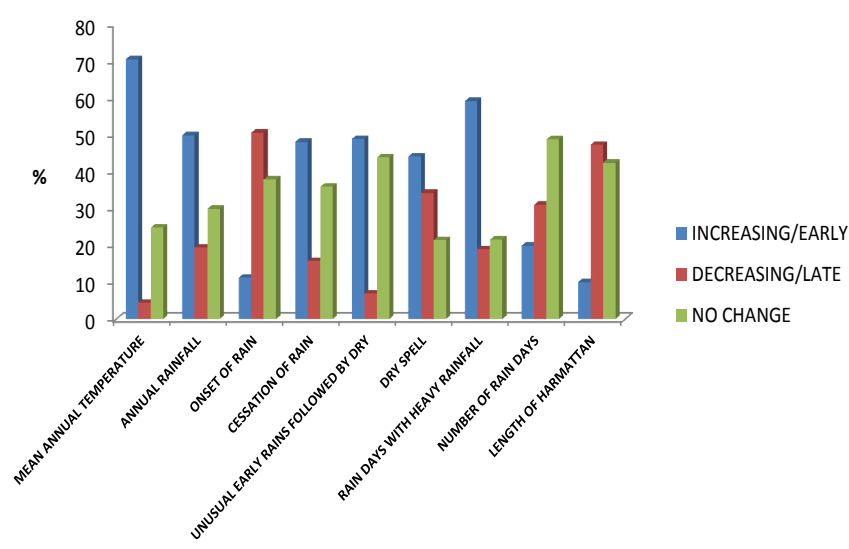

Figure 3: Smallholder farmers' perception of climate change and variability over the last 30 years in U \& LNRBDA.

\begin{tabular}{|c|c|}
\hline Food crops & Percentage (\%) \\
\hline Yam & 89.2 \\
\hline Cassava & 87.1 \\
\hline Rice & 45.6 \\
\hline Maize & 88.4 \\
\hline Guinea corn & 69.2 \\
\hline Millet & 56.1 \\
\hline Beans & 57.2 \\
\hline Melon & 49.0 \\
\hline
\end{tabular}

Table 1: Major food crops produced in U \& LNRBDA.

was not the case in time past. Majority of the respondents $(50.7 \%)$ perceived a delay in the onset of rain in many more years than 30 years ago while 38 percent agreed that the onset of rainfall has not changed significantly but varied from year to year. Some of the smallholder farmers quickly remarked that incident of unusual early rain followed by long dry spell is increasing which rarely occurred about 30 years ago. 48.2 percent of the farmers observed rain cessation to be earlier while 36 percent of them perceived that the time of cessation of rains had not changed. However, 44.2 percent of the respondents perceived that dry spells particularly during the growing season were becoming common in the study area. High proportion of the respondents $48.9 \%$ did not notice any change in the number of rain days in the last 30 years. 47.4 percent of the respondents observed that the length of harmattan in the study area is decreasing while 42.5 observed no change. A similar study by Mary and Majule in Singida region of Tanzania reported that a significant number of farmers perceived increase in temperature [10], late onset of rain, decrease in precipitation and increase in frequency of drought over the past ten years.

From the farmers' perception of climate it is safe to say that the smallholder farmers in the study area have shrewd knowledge of the climate of their region and that there is high level of climate change awareness in the area. Smallholder farmers' perceptions with respect to temperature are closely related to empirical analysis of temperature data obtained from meteorological station. Variability analysis of temperature in the study area indicated that annual temperature increased from 1951-2010 but particularly from 1993-2010 [11]. Annual mean temperature over the period 1951-2010 showed an increase of $0.45^{\circ} \mathrm{C}$ in the study area. This increase in temperature may be regarded as moderate and that must have accounted for why there is a sizeable number of respondents who could not detect it (Table 2). Hulme found that Africa has warmed at a mean rate of $0.5^{\circ} \mathrm{C}$ throughout the twentieth century with the six hottest years having occurred in the period 1987-1998 [12]. Annual rainfall over the study area exhibits multidecadal drying trend from 1970-1993, increasing trend during 1994-2010 with strong inter annual variability [13]. This pattern of rainfall change validates the perception of the respondents (Table 2). New noted a wetter condition in the Sahel in the 1990s which continued into the beginning of the $21^{\text {st }}$ century [12]. Also Babatolu reported an increasing trend in heavy rainfall in U\&LNRBDA [14]

\section{Smallholder farmers' perception of the impact of climate change and variability on crop production in the study area}

Based on smallholder farmers' survey in the U \& LNRBDA, it is apparent that climate change and variability had already affected crop production in the area. According to them in most years climate extremes have led to poor harvest and increase in food price. The most important perceived effects of climate change and variability on crop production are listed in Table 2.

False start of rain: Majority of respondents (69.7\%) reported frequently experiencing good rains at the beginning of the raining season followed by dry spells. Smallholder farmers were always tempted to plant seeds with the early rains which were scorched during the dry spells. This requires farmers to undergo several rounds of sowing seeds which were scarce and limited. According to the respondents farmers who plant after the first or second rain usually run into huge loss when dry spells are prolonged due to climate variability. The crops were scorched causing huge economic loss. Few of the respondents volunteered to say that in the period before 1980s farmers could predict the rain almost accurately and they knew precisely when to plant their crops. But because of climate change and variability farmers could no longer determine when to plant and when to harvest. They are losing control and initiative to climate change.

Dry spells and drought: Closely related to this is dry spells and drought which frequency occurs within the growing season. Respondents $(76.6 \%)$ claimed to experience dry spells during the raining season which sometimes lead to drying, scotching of crops and ultimately retards crop growth and reduce yield. Few respondents recalled that whenever dry spell occurred at the critical periods of crops it led to low yield or crop failure.

High temperatures: Significant number of smallholder farmers (89.9\%) perceived that high temperatures particularly at the beginning of the rains and during long spells usually burn germinating seeds. In the Lower Niger River Basin Development Authority (LNRBDA), smallholder farmers reported a great loss of early yam seed through scorching of sprouting yam in February and March when high temperature and low rainfall were always experienced. Smallholder farmers in the study areas also noted scotching of germinating maize seeds in March/April. Respondents observed that rains were readily evaporated by high temperature emphasizing that few hours after

\begin{tabular}{|c|c|}
\hline Impacts & Respondents \\
\hline False start of rain & 69.7 \\
\hline Dry spells & 76.6 \\
\hline High temperature & 88.9 \\
\hline Decreasing soil fertility & 80.5 \\
\hline Floods & 79.6 \\
\hline Shortening of growing season & 69.2 \\
\hline Pests and diseases & 45.6 \\
\hline
\end{tabular}

Table 2: Perceived impacts of climate change and variability on crop production in the study area. 
Citation: Babatolu JS, Akinnubi RT (2016) Smallholder Farmers' Perception of Climate Change and Variability Impact and Their Adaptation Strategies in the Upper and Lower Niger River Basin Development Authority Areas, Nigeria. J Pet Environ Biotechnol 7: 279. doi:10.4172/21577463.1000279

rain must have fallen, the soil would appear dry because of high temperatures. According to them high temperature resulted in dryness of soil which always resulted in poor germination, crop failure and even low yield. The rainfed crops are close to their critical temperature beyond which yield many drastically reduce [1].

Decreasing soil fertility: Some respondents $(80.5 \%)$ remarked that the temperature and frequent heavy rainfall in the last few years caused accelerated erosion and reduction in soil fertility. According to some of them in the absence of fertilizer crop yields drops.

Floods: Large percentage $(79.6 \%)$ of respondents perceived that rain was becoming heavier leading to incessant floods in the study area. According to the smallholder farmers, flood affect crop production in the study area through washing away/destruction of crops and hence reduction in yield or crop failure. Many communities were always isolated due to washing away to bridges and culverts preventing farmers from carrying their farm products to towns for sale according to some of the respondents. In this situation large proportion of crops produced either perished or were disposed cheaply. Washing away of crops was very rampant along streams and rivers and affect rice and sugarcane plantations mainly. 1998, 1999, 2003, 2007, 2011 and 2012 were cited by different respondents as years of disastrous floods in the study areas but agreed that the study area was worst hit in the 2012 when not only farms were washed away but houses.

Pests and diseases: Smallholder farmers (45.4\%) acknowledged significant increase to crop damage by pests and diseases including weed. Increase in temperature and rainfall was related to proliferation of pests and diseases by the respondents. Pests and diseases observed in the survey include stalk borers which attack maize, mottle yellow virus, bird and grasshoppers which attack rice, rapid growth of weeds which attack all crops and mosquitoes which cause malaria fever. According to the respondents pests and diseases heightened crop failure although they couldn't place the effects of malaria fever on agricultural production.

Shortening of growing season: A significant (69.2\%) reported experiencing unpredictable and unreliable onset and retreat of rains and shrinking of the growing season. According to them more often than not crops grown found it difficult to survive and have good yield. Respondents cited the experience of smallholder farmers in the wetter southern part of the study area where climate supports the production of early maize (April - July) and late maize (July - October) before 1980s but which can hardly support it in most years in the last 25-30years. Guinea corn and rice also suffer the same fate particularly during the flowering period. This implies increase risk of crop failure due to reduction in the length the growing season.

\section{Smallholder farmer's adaptation strategies to climate change impacts on crop production in U \& LNRBDA areas}

Smallholder farmers in the study area have in many cases adapted their farming to climate change and variability. They have built tremendous indigenous knowledge of their environment to secure their livelihoods with locally available resources. The developed overtime remarkable adaptation ability by practicing a diversified traditional farming systems and dry season farming. Some of the coping strategies are discussed below:

Scattering of cultivated land areas: Large proportion of smallholder farmers in the study area do not farm on one site rather, they scatter their farms such that a farmer may have two to three plots of farm far apart from one another planted with the same type of crops.
This is based on the indigenous knowledge of the farmers that rainfall in the study areas is highly localized - that is not uniformly distributed over large area. The importance of these strategies is that smallholder farmers do not lose everything in case rainfall fails in one area as it may be good in others. Farmers do this to take advantage of the differences in small areas in terms of rainfall amount, soil nutrient and temperature within a region.

Staggered seed crop planting: To solve the problem of erratic and unpredictable onset of rains perceived by the smallholder farmers in the study area crops are planted at different dates. Few smallholder farmers plant part of their seeds after the first and second rain then wait for the rain to fall regularly enough before embarking on the major planting. For instance, some smallholder farmers in Lower Niger River Basin Development Authority areas (LNRBDA) plant the first set of their yam in September/October to take the advantage of the last rains and plant another set in April at the onset of the rains. According to the farmers, this strategy reduces the risks of total crop failure and waste of seedlings.

Intercropping: This is farming method whereby a main crop is planted with one or two crops planted in-between as subsidiaries or low density. Farmers gave instances where yam (tuber) may be planted as the main crops while maize (cereal) and melon (legume) are planted as subsidiaries at different time in the growing season. According to farmers, this method increases total crop harvest and maximize the microclimate.

Multiple cropping: This is a method whereby many crops are planted at the same time on a piece of land. This is very common in the study area. Farmers may decide to plant two to four crops on the same plot depending on an individual. Many combinations of crops were given by the farmers such as yam, cassava, pepper, okro etc. According to the farmers the crops are not always planted at same time bur at different time during the growing season.

From our interactions with smallholder farmers in the study area, it is noted that they have good knowledge of advantages of intercropping and multiple cropping in terms of maturity period of crops, their water requirements and end uses of the product. The farmers revealed that those that practice these strategies suffered less damage than their counterpart using monocultures. The strategies minimizes risks of total crop loss due to climate change and variabilities impacts as the crops planted differ in moisture and heat requirements and even maturity time. They maximize soil moisture, reduces heat, evaporation and erosion because of the cover provided. Importantly they promote diet diversity.

Diversification of crops: In the study area it was revealed that smallholder farmers do not depend on a single food crop (monoculture) but cultivate diversity of crops on one or move plots of land. According to respondents farmers hardly plant less than there major food crops in a year. Diversification of crops allows smallholder farmers to avert risks and maximize harvest security under unpredictable and unreliable climate. It has the advantage of allowing all types of land to be used by the farmers. For instance, in many communities in the LNRBDA area, sweet potato and cocoyam are becoming important food crops. This is because their climate requirements are easily met than the major food crops such as yam.

Intensive farming: Rice farmers in the Upper Niger Basin Development Authority are (UNRBDA) practise intensive agriculture. It is also practised in other parts of the study area on fadama. It is a system whereby double - or treble - cropping is done on the same plot 
Citation: Babatolu JS, Akinnubi RT (2016) Smallholder Farmers' Perception of Climate Change and Variability Impact and Their Adaptation Strategies in the Upper and Lower Niger River Basin Development Authority Areas, Nigeria. J Pet Environ Biotechnol 7: 279. doi:10.4172/21577463.1000279

Page 6 of 7

of land in the course of the year. This is made possible by the use of small scale irrigation and application of manure or fertilizer. According to the farmers this strategy helps in spreading risk of crop loss through washing away of farms by floods and rain failure.

Mulching: The farmers were also able to exhibit their knowledge of the effect of temperature on cropping. According to smallholder farmers, mulching is used to prevent massive burning of sprouting yams during period of high temperature. When heaps of yam are capped with leaves or grasses, the heat that can penetrate to the yam seed will be reduced. This prevent planted seeds from getting rotten, the spout from burning and crop loss is reduced. According to the respondents, mulching reduces the temperature of the soil and conserves moisture in the immediate environment of the planted seeds.

Soil tillage practices: Some farmers in the study area bury crop and weed residues in the heaps ploughed for planting so as to replenish soil fertility on decaying. They also use contour ridges as a strategy to reduce accelerated erosion on slopes. Weed residues and leaves cut off from shrubs or tree stumps were always neatly arranged on the furrow to check surface runoff and erosion; many of the farmers remarked. In this practice, farmers attempt to maintain cycles of materials and wastes.

Fadama: Fadama are wetlands found along rivers/streams or low lying area (swanpy). These are most extensive along river Niger, kaduna Kontagora and Gurara. Sizable ones are also found along small streams and lowland in the interior area. Under traditional farming conditions, the fertility of alluvial soils found in fadamas is at its peak during the dry season when flood waters of rivers recede. The flat topography of areas of such alluvial soil, the moderate accumulation of organic matter and the presence of water table near the surface render them eminently suitable for intensive farming with or without the use of irrigation. The smallholder farmers in the study area use fadama to cultivate early yam, maize, rice and some other crops. Fadama encourages dry season farming and is a good coping strategy with drought and floods.

Granaries: Many farmers keep their excess harvest in granaries for the off-season time when food is always scarce and costly. The crops that lend themselves to being preserved by the farmers are grains including sorghum, millet and maize. In case of tubers (yam) many farmers preserve their yams by trying them on sticks to prevent their easy decay. Further more many farmers preserve their yams and cassava by peeling, cutting them into pieces; soak in warm/cold water for few days then sundry them. These strategies ensure food security and stabilize food prices.

Use of improved crop varieties: It should be remarked that some farmers responded to shrinking growing season, dry spells and drought by adopting improved crop varieties. The use of improved varieties was mentioned in connection with early maturity and high yielding maize, rice and sorghum by farmers.

Shifting of crop production: Many smallholders farmers who felt that guinea corn yield was decreasing drastically in the study area due to erratic rainfall and shortening of the growing season were shifting to planting of millet. Millet which is cultivated mainly in the UNRBDA is now becoming a preferred crop to guinea corn, one of the most important traditional grain in the LNRBDA as the rainfall requirement for the production of guinea corn is no longer met in the area in most of the years.

Irrigation: Smallholders farmers practice irrigation particularly in the UNRBDA where rainfall amount is small and unpredictable. Irrigation methods include shadoofs and canal irrigation. Shadoofs are used to supplement the rainfall and water supplied by the seasonal floods. Canal irrigation involves the controlling of flood water which is led through canal to the farms. Again when the flooded water of the fadama subsides, it leaves behind wet soil enriched with silt. Rice and cane sugar can be planted on the soil. Irrigation gives room for dry season farming and increase crop production, according to the smallholder farmers.

This study suggests that smallholder farmers had detailed knowledge of climate variables (temperature, rainfall etc.) and their impacts on their crops. Over the centuries, generations of smallholder farmers in the study area used skillful combinations of techniques and practices to develop different and locally adapted agricultural systems which stabilize their crop production. These systems results from the long period of interaction between the farmers and their environment using experiential knowledge and locally available resources. Their wealth of experience and knowledge in management and use of local natural resources in the face of climate change and variability allow them avert risks and maximizes harvest. The study also shows that the different traditional systems and indigenous technologies such as scattering of cultivated plot of land, intercropping, multiple cropping, crop diversification, local irrigation, mulching amongst others minimize crop failure, increase harvest stability and reduce vulnerability to climate change and variability. Diversifications of crops in particular ensure diverse diet and protest the smallholders' income from the risk of climate change.

The important features of the traditional farming systems in the study area emerging from this research include

I. Cultivation of diversity crops which plays a vital role in minimizing the impacts of climate change on harvest.

II. Many of the smallholder farmers still rely on manual labour using hand tools (hoe and cutlass) to cultivate their land and also making use of local resources. This is an important coping strategy with heavy rainfall which can result in large - scale soil erosion if the soil is exposed by heavy machines thus decreasing soil fertility.

III. Farmers rely mainly on local varieties of crops. Many are yet to have access to improved varieties.

IV. Traditional system of farming is on self-sufficient basis and farmers produce food for themselves and their families. Small surpluses are sold to meet their other need especially the children education. With these practices smallholder farmers have built tremendous knowledge to secure their livelihood over the years.

It is true that many farmers in the study area suffer different degrees of loss from year to year but they always bounce back coping successfully. Climate scientists are painting a gloomy picture of agricultural productivity for African farmers based on the fact that farming activities in many parts of Africa is solely dependent on rainfall. The analyses in this study revealed that the fears expressed over the vulnerability of smallholder farmers to climate change and variability in the study area underrated the high level of their coping capabilities. Available data is just a gross approximation at understanding the heterogeneity of small scale agriculture, ignoring the myriad of strategies that thousands of smallholder farmers have used and still use to deal with climate variability [15]. Though the coping strategies adopted by the smallholder farmers enhance resiliency, it is not sufficient to achieve sustainability. It is therefore, essential for the government to identify the farming methods that are sustainable and improve on them in order to reduce vulnerability and enhance the adaptive capacity of the farmers $[16,17]$. 
Citation: Babatolu JS, Akinnubi RT (2016) Smallholder Farmers' Perception of Climate Change and Variability Impact and Their Adaptation Strategies in the Upper and Lower Niger River Basin Development Authority Areas, Nigeria. J Pet Environ Biotechnol 7: 279. doi:10.4172/21577463.1000279

In designing adaptation policy by the government emphasis should be placed on the local knowledge of the smallholder farmers, role of local institutions and local governance. The imported farming technologies introduced by the government to sustainably improve the livelihood of smallholder farmers failed because the traditional Knowledge of the farmers was underrated. The technologies are foreign to them and their environment and hence failed to meet their needs and improve their lots. Adaptation is a local process so local farmers must be at the centre of the adaptation planning. Their indigenous knowledge is indispensable in adaptation planning. Local communities' choice of coping strategies depends on their resources, agency, social background and value $[18,19]$.

\section{Conclusion}

The people of the study area are largely smallholders farmers' relying on rainfed agriculture for their livelihood. Many generations of farmers here have developed diverse local strategies achieved through time-tested skilled combination of technique and practice that lead to production of food in sufficient quantity while preserving the natural resources and biodiversity. These local strategies which include crop diversification, multiple cropping, mixed - cropping and planting on different plots of land at a time and so on represent the accumulated experiences of farmers interacting with their environment.

Predictions suggested that anticipated changes are expected to affect the developing world more than the rest of the world, particularly, the subsistence farmers who rely heavily on rainfed farming. This study, however, shows that smallholder farmers' indigenous knowledge of climate change and variability, its impacts and socio-economic consequences has proved invaluable for meaningful adaptation to cope with risks and threats of climate change and variability. Smallholder farmers' in the study area use many effective strategies to deal with climate variability. The accumulated knowledge and experience of smallholder farmers in the study area in coping with large natural climate variations from year to year notwithstanding, rapid climate change could jeopardize agricultural production. The government will, therefore, need to add to their capacity to adapt by providing good governance, better infrastructure, access to market, credit, good health service education, access to information and fairness in distribution of resources amongst others.

\section{Acknowledgement}

The authors appreciate TETFUND whose financial support made this study possible. The authors also acknowledge the Nigeria Meteorological Agency for the rainfall data.

\section{References}

1. IPCC (2001) Climate Change 2011: Impacts, vulnerability and adaptation contribution of working group III to the third assessment report. International governmental Panel on Climate Change. Cambridge University Press.

2. Falaki AA, Akangbe AA, Ayinde OE (2013) Analysis of climate change and rura farmers' perception in North Central Nigeria. J. Hum Ecol, 43: 133.140.

3. World Bank (2011) "Policy Brief 2012: Opportunities and challenges for climate smart agriculture in Africa” pp: 1-4.
4. FAO (2012) Towards the future we want and hunger and make the transition to sustainable. Agricultural and Food System, Rome.

5. Onyeneke RU, Madukwe DK (2010) Adaptation measures by crops farmers in the southeast rainforest zone of Nigeria to climate change. Science World Journal 5.

6. Odjugo P, Ovuyorwiroye A (2010) Adaptation to climate change agricultura sector in the semi-arid region of Nigeria. A paper presented in 2000 International Conference: Climate sustainability and development in Semi-arid regions. August 16-20, 2020, Fortaleza -Ceara Brazil.

7. Farauta BK, Egbule CL, Agwu AE, Idrisa YL, Onyekuru NA (2012) Farmers' adaptation initiatives to the impact of climate change on agriculture in northern Nigeria. Journal of Agricultural Extension 16: 132-144.

8. Fatause Al, Ajibefun Al (2013) Adaptation to climate change: A case study of rural farming households in Ekiti State, Nigeria. Impact World 2013 International Conference On Climate Change Effects. Potsdam, May 22-30.

9. Nkeme KK, Ndaeyo NU (2013) Climate changes and coping strategies among peasant farmers in Akwa Ibon State, Nigeria. International Journal of Basic Applied Science. 2: 24-28.

10. Mary AL, Majule AE (2009) Impacts of climate change. Variability and adaptation strategies on agriculture in semi and areas of Tanzania, Africa Journal of Environmental Science and Technology 3: 206-218.

11. Babatolu JS, Akinnubi RT (2013) Surface temperature anomalies in the rive niger basin development authority area, Nigeria. Atmosphere and Climate Sciences 3: 523-537.

12. New MG, Hulme M, Jones PD (2000) Representing $20^{\text {th }}$ century space-time climate variability. Part II: Development of 1901-1996. Monthly Terrestrial Climate Fields. Journal of Climate 3: 2217-2238.

13. Babatolu JS, Akinnubi RT, Akintade TF, Omosuyi OB (2013) An investigation of rainfall variability in the upper and lower river niger basin development authority areas, Nigeria. Int. Journal of Basic and Applied Science 2.

14. Babatolu JS, Akinnubi RT, Akintade TE, Omosuyi OB (2014) Variability and trends of daily heavy rainfall events over Niger river basin development authority area, Nigeria. American Journal of climate Change 3: 1-7.

15. Attieri MA, Toledo VM (2005) Natural resources management among small scale farmer in semi-arid lands: Building on the traditional knowledge and agroecology. Annual of Arid Zone 44: 365-385.

16. IPCC (2007) Summary for policymakers In: climate change 2007: Impacts adaptation and vulnerability, Contribution of working Group II to the Fourth Assessment Report of the Intergovernmental Panel on Climate Charge, M.L. Parry O.F., Canziani, J.P Palutikof, P.J Vander Lunden and C.E. Hanson (eds) Cambridge: Cambridge University Press.

17. National Research Council (NRC) (2010) Adapting to the impacts of climate change. America's climate choices: Panel on adapting to the impacts of climate changes. National Academics of Science.

18. Pelling M, High C (2005) Understanding adaptation: What can social capital offer assessments of adaptive capacity? Global Environmental Change A.15 308-319

19. http//climatecharge.worldbank.org/sites/default/files/documents/CSApolicty 